\title{
Response of Pear Trees' (Pyrus bretschneideri 'Sinkiangensis') Fine Roots to a Soil Water Regime of Regulated Deficit Irrigation
}

\author{
Yang $\mathrm{Wu}^{1, *}$, Zhi Zhao ${ }^{2,3}$, Feng Zhao ${ }^{1,3}$, Xiaolei Cheng ${ }^{1,3}$, Pingping Zhao ${ }^{1}$ and Songzhong Liu ${ }^{1, *}$ \\ 1 Institute of Forestry and Pomology, Beijing Academy of Agriculture and Forestry Sciences, Key Laboratory of \\ Biology and Genetic Improvement of Horticultural Crops (North China), Ministry of Agriculture and Rural \\ Affairs, Beijing Engineering Research Center for Deciduous Fruit Trees, Beijing 100093, China; \\ fengzhao20@cau.edu.cn (F.Z.); cheng_xl@cau.edu.cn (X.C.); zzz158888888@163.com (P.Z.) \\ 2 Department of Irrigation and Drainage, China Institute of Water Resources and Hydropower Research, \\ Beijing 100048, China; zhaozhi@iwhr.com \\ 3 College of Engineering, China Agricultural University, Beijing 100083, China \\ * Correspondence: wuyang@baafs.net.cn (Y.W.); Liusongzhong@baafs.net.cn (S.L.); \\ Tel.: +86-10-6259-1346 (Y.W. \& S.L.)
}

Citation: Wu, Y.; Zhao, Z.; Zhao, F.; Cheng, X.; Zhao, P.; Liu, S. Response of Pear Trees' (Pyrus bretschneideri 'Sinkiangensis') Fine Roots to a Soil Water Regime of Regulated Deficit Irrigation. Agronomy 2021, 11, 2316. https://doi.org/10.3390/ agronomy11112316

\section{Academic Editor: Sara Serra}

Received: 13 September 2021

Accepted: 12 November 2021

Published: 16 November 2021

Publisher's Note: MDPI stays neutral with regard to jurisdictional claims in published maps and institutional affiliations.

Copyright: (c) 2021 by the authors. Licensee MDPI, Basel, Switzerland. This article is an open access article distributed under the terms and conditions of the Creative Commons Attribution (CC BY) license (https:/ / creativecommons.org/licenses/by/ $4.0 /)$.

\begin{abstract}
A field experiment was conducted to evaluate the effects of regulated deficit irrigation (RDI) on the fine root redistribution of mature pear trees in 2009 and 2010. The experiment consisted of four RDI treatments: MRDI-1 and SRDI-1, in which the trees received irrigation replacing $60 \%$ and $40 \%$ of pan evaporation (Ep) during Stage 1 (cell division stage), and MRDI-1+2 and SRDI-1+2, in which the trees received irrigation replacing $60 \%$ and $40 \%$ of Ep during Stage 1+2 (cell division and slow shoot growth stage). All the RDI-treated trees received irrigation replacing $80 \%$ of $E p$ (full irrigation) in other stages, and the control trees were fully irrigated during the whole growth season. The results showed that the fine root length density (RLD) of mature pear trees was reduced by water stress. The resumption of full irrigation boosted fine root growth. The RLD of the SRDI-1-treated trees in the irrigated zones recovered in early July, they maintained water and nutrient absorption during the fruit enlargement stage, and the final fruit yield was significantly improved. The RLD of trees in the irrigated zones with MRDI-1 and MRDI-1+2 recovered in July and September, respectively, but there were no significant differences in fruit yield between the MRDI-1, MRDI-1+2, and the control. This indicates that the fruit yield was not negatively or positively impacted by the redistribution of moderate water stress applied during either Stage 1 or Stage $1+2$.
\end{abstract}

Keywords: pear tree; root length density; tree growth; yield

\section{Introduction}

Fine roots are mainly responsible for the uptake of water and nutrients [1], especially in arid regions with high competition for water between trees and crop plants. Knowledge of fine root distribution is essential for the effective design and management of agroforestry systems [2-5]. Fine root growth and distribution are affected by many factors, and soil water status is one of the key factors. Soil water status is impacted by irrigation scheduling and affects the growth and redistribution of fine roots. In particular, soil water deficit irrigation usually induces restricted root growth and activity [6-8]. Full irrigation produces higher root length density in potatoes compared to deficit irrigation [9], and winter wheat enduring water stress has less root biomass and a lower ratio of root biomass to root length [10]. The size of a root system has long been recognized as crucial to cope with drought conditions [11], and water stress inhibits shoot growth more significantly than root growth, leading to a greater root/shoot ratio [6,11,12].

The regulated deficit irrigation (RDI) strategy can effectively improve water use efficiency and has been widely used in semi-arid and arid regions. The RDI imposes water 
stress, which inhibits vegetative growth, while full irrigation resumes during the fruit enlargement period in order to improve the yield or fruit quality [13-16]. The vegetative growth is influenced by the degree and duration of the water deficit; the growth rate decreases with an increasing degree and duration of water deficit, and a severe and long water deficit may result in a significant decline in final yield. During the water deficit periods, fine root growth is inhibited, and then recovers after the resumption of full irrigation in the fruit enlargement stage. The recovery of fine root growth during the fruit enlargement stage requires leaf photosynthetic products, which may be competitive with fruit growth and result in a decline in fruit yield. Thus far, the impacts of RDI on the growth and yield of pear trees [15-23] and other fruit trees [24-32] have been reported by many researchers. Nevertheless, the impacts of water stress, imposed before the fruit enlargement stages, on fine root variation and its effects on the growth of pear trees and fruit yield are not well discussed in previous studies. Thus, it is difficult to evaluate the impacts of water stress and the resumption of full irrigation in the RDI strategy on the fine root variation of fruit trees and its effects on fruit trees' growth and fruit yield.

Therefore, this research was conducted in an extremely arid region, and the objective was to find out (1) the responses of the fine root of mature pear trees (Pyrus bretschneideri 'sinkiangensis') to water stress imposed during different growing stages, and the resumption of full irrigation during the rest of the stages, and (2) the potential impacts of fine root redistribution on tree growth and fruit yield.

\section{Materials and Methods}

\subsection{Experimental Material and Location}

The experiment was conducted in 2009 and 2010, from the middle of April to early September, in southwestern Korla $\left(41^{\circ} 43^{\prime} \mathrm{N}, 86^{\circ} 6^{\prime} \mathrm{E}\right)$, Xinjiang, China. The experiment orchard is located in an oasis in the Taklimakan desert. The climate of the experimental site is extremely dry with a mean annual temperature of $11.4^{\circ} \mathrm{C}$ and an average annual rainfall of $50 \mathrm{~mm}$, while the mean annual evaporation reaches $1600 \mathrm{~mm}$. During the experimental period, the evaporation was $800 \mathrm{~mm}$ and $773 \mathrm{~mm}$ in 2009 and 2010, respectively, and the precipitation in 2009 and 2010 was $21.2 \mathrm{~mm}$ and $24 \mathrm{~mm}$, respectively (Table 1). The soil in the experimental orchard is silt loam, consisting of $5.6 \%$ clay, $44.0 \%$ sand, and $50.4 \%$ silt. From the soil surface to a depth of $1.5 \mathrm{~m}$, the average soil bulk density is $1.5 \mathrm{~g} / \mathrm{cm}^{3}$. The pear trees (Pyrus bretschneideri 'sinkiangensis') grafted on the rootstock of Pyrus betulaefolia, planted at $6 \mathrm{~m} \times 5 \mathrm{~m}$ (333 tree/ha), were 24 years old in 2009. The experimental pear trees were watered by two driplines, which were located on each side of the tree row, and the distance between the tree row and dripline was $1 \mathrm{~m}$. The emitter space was $0.5 \mathrm{~m}$ along the laterals, which had an outside diameter of $16 \mathrm{~mm}$. The discharge rate of emitters was $2.8 \mathrm{~L} / \mathrm{h}$.

Table 1. Precipitation, evaporation, and irrigation amount of each treatment.

\begin{tabular}{ccccccccc}
\hline \multirow{2}{*}{ Year } & Stages & \multirow{2}{*}{ Precipitation $(\mathbf{m m})$} & Evaporation $\mathbf{( m m})$ & \multicolumn{4}{c}{ Irrigation Amount (mm) } \\
\cline { 5 - 9 } & & & MRDI-1 & SRDI-1 & MRDI-1+2 & SRDI-1+2 & Control \\
\hline \multirow{2}{*}{2009} & Stage 1 & 2.4 & 171.5 & 94 & 58 & 94 & 59 & 122 \\
& Stage 2 & 9.2 & 364.8 & 306 & 308 & 222 & 144 & 310 \\
& Stage 3 & 9.6 & 264.0 & 226 & 229 & 224 & 227 & 227 \\
& Total & 21.2 & 800.3 & 626 & 595 & 540 & 430 & 659 \\
\hline \multirow{2}{*}{2010} & Stage 1 & 9.2 & 136.5 & 74 & 44 & 73 & 44 & 97 \\
& Stage 2 & 12.6 & 319.3 & 261 & 261 & 187 & 135 & 260 \\
& Stage 3 & 2.2 & 317.5 & 271 & 275 & 274 & 273 & 274 \\
& Total & 24.0 & 773.3 & 606 & 580 & 534 & 452 & 631 \\
\hline
\end{tabular}

Note: Stage 1 was the cell division stage (from the middle of April to the middle of May, 0-30 DAB), Stage 2 was the slow shoot growth period (from the middle of May to the beginning of July, 31-86 DAB), and Stage 3 was the fruit enlargement period (from the beginning of July to harvest, 87-147 DAB). MRDI-1 and SRDI-1 were applied with moderate and severe water stress, respectively, during Stage 1, and fully irrigated during other stages; MRDI-1+2 and SRDI-1+2 were applied with moderate and severe water stress applied during Stage 1+2, respectively, and fully irrigated during other stages. 


\subsection{Experimental Design}

The full bloom date of the experimental pear trees was April 10 and 15 in 2009 and 2010, respectively. According to the research of Yan et al. [33], the whole growing season of the experimental pear trees is divided into three periods, including the cell division period, from full blooming to 30 days after full blooming (DAB); the slow fruit and shoot growth period, 31-86 DAB; and the fruit enlargement period, 87-147 DAB.

The experiment comprised four RDI treatments and a control treatment. The moderate (MRDI-1) and severe (SRDI-1) regulated deficit irrigation treatments were carried out using irrigation equivalent to $60 \%$ and $40 \%$, respectively, of pan evaporation during Stage 1 (cell division stage), and irrigation replacing $80 \%$ of pan evaporation in the other stages. The moderate (MRDI-1+2) and severe (SRDI-1+2) regulated deficit irrigation treatments consisted of irrigation replacing $60 \%$ and $40 \%$, respectively, of pan evaporation during Stages 1 and 2 (Stage 2, slow fruit and shoot growth stage), and irrigation replacing 80\% of pan evaporation in Stage 3 (fruit enlargement stage). The control treatment received irrigation replacing $80 \%$ of pan evaporation during all stages. The first irrigation was conducted on April 12 and 17 in 2009 and 2010, respectively. All plots were irrigated weekly; the irrigation amount is shown in Table 1. The experimental orchard was flood irrigated and shifted to surface drip irrigation at the end of 2008. The experiment was a completely randomized design, and each of the treatments were repeated three times. Every repetition consisted of two pear trees, which were surrounded by the ten guard trees in three rows.

\subsection{Measurements}

\subsubsection{Soil Moisture and Evaporation Measurements}

Soil water status was measured by a capacitance probe (Diviner 2000, Sentek Pty Ltd., Stepney, SA, Australia). Two access tubes per repetition were installed at a depth of $1.5 \mathrm{~m}$. One was just under the dripline in the irrigated zones, and another was $2 \mathrm{~m}$ away from the tree row and opposite the tree trunk in the non-irrigated zones. The volumetric soil water content was measured immediately before each irrigation event, and the readings were converted into soil water potential [23]. A USA class A pan was installed near the experimental site to monitor evaporation, and the measurement was conducted daily.

\subsubsection{Tree Measurements}

One tree per replication was selected in order to measure the fine root length with a root diameter of less than $1 \mathrm{~mm}$ [34-36]. Root sampling of the experimental trees was conducted in early July (end of the water deficit cycle, 87-90 DAB) and in the middle of September (after fruit harvest, 150-155 DAB) in 2009 and 2010. Two sampling points per plot were located between tree rows, $1 \mathrm{~m}$ (Location A, irrigated zone) and $2 \mathrm{~m}$ (Location B, non-irrigated zone) from the trunks (Figure 1). Along the tree rows, the roots were sampled once per repetition at a horizontal distance of $1 \mathrm{~m}$ (Location $\mathrm{C}$, non-irrigated zone) from the trunk (Figure 1). In the middle of May of 2010 (30-35 DAB), the root of MRDI-1, SRDI-1, and the control treatments were sampled at point A. From soil surface to a depth of $0.9 \mathrm{~m}$, roots were sampled using a drill with an inside diameter of $100 \mathrm{~mm}$ and divided into three layers: $0-20 \mathrm{~cm}, 20-60 \mathrm{~cm}$, and $60-90 \mathrm{~cm}$. The roots were separated from the soil by means of wet sieving and visually inspected to remove root of other species [4]. The length of the root samples was measured using the WinRHIZO root analysis system (Regent Instrument Inc., Quebec, QC, Canada). The root length density (RLD) was the ratio of the fine root length to the corresponding sampling volume. 


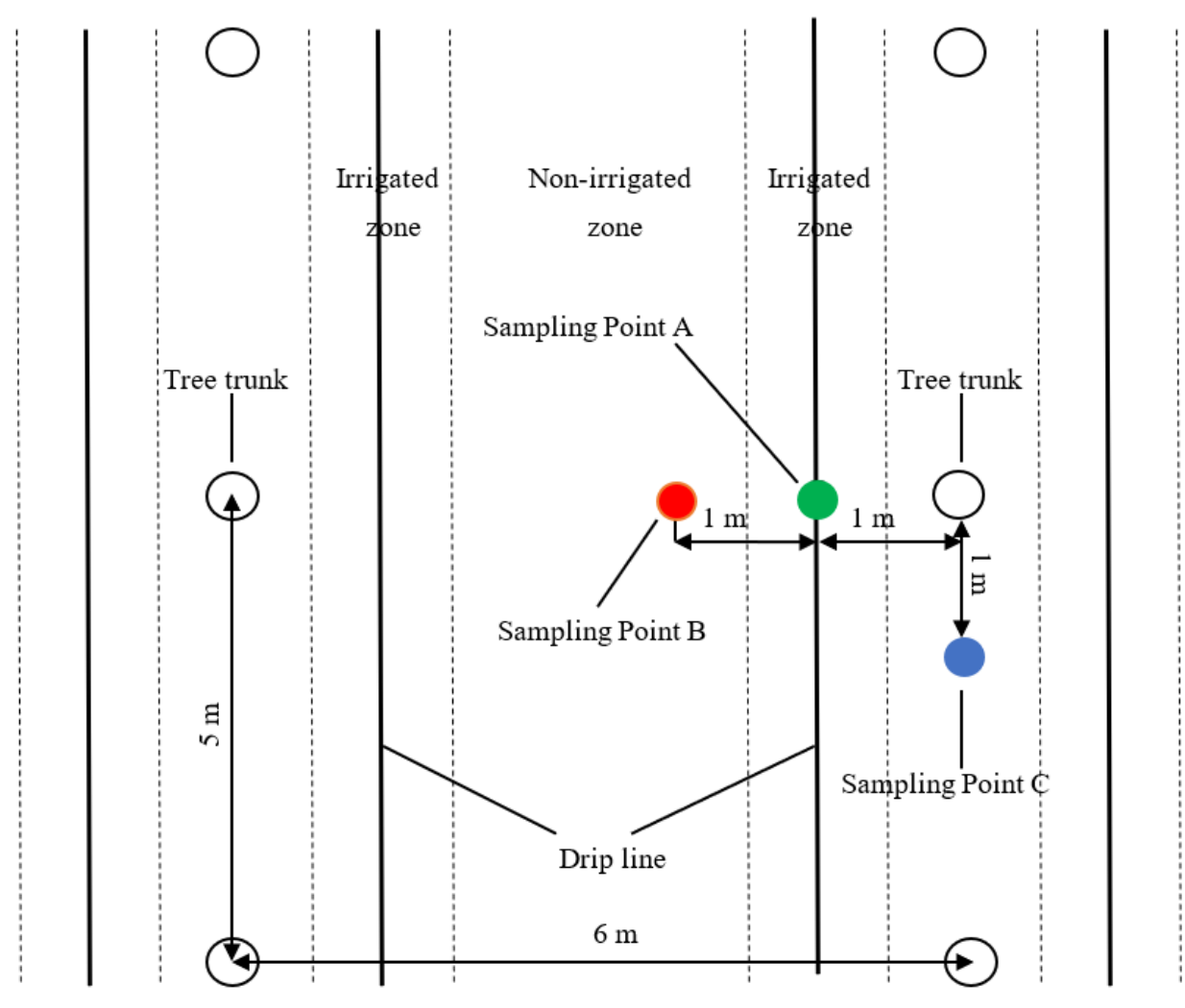

Figure 1. Sketch of root sampling and driplines layout. The sampling point A (irrigated zone) was located between tree rows and $1 \mathrm{~m}$ away from the trunk; the sampling point B (non-irrigated zone) was located between tree rows and $2 \mathrm{~m}$ away from the trunk; the sampling point $\mathrm{C}$ (non-irrigated zone) was located along the tree row and $1 \mathrm{~m}$ away from the trunk. Two driplines (solid line) were located on each side of the tree row, and the distance between the tree row and dripline was $1 \mathrm{~m}$. The dashes lines on each side of the dripline represent the wetted zone of the dripline, with a width of $1 \mathrm{~m}$.

The leaf photosynthetic rate $(P n)$ measurements were taken from 10:00 a.m. to 11:30 a.m. on three sunny days during each stage. Two healthy leaves per replicate were randomly labeled at the same position of the canopy, and the leaf photosynthetic rate was measured two times with a photosynthesis system (CB-1102, Yaxinliyi Science and Technology Co., Ltd., Beijing, China). Twenty shoots from the south part of the canopy per replication were labeled, and shoot length was measured weekly with a measuring tape. Fruits of the sample trees were harvested by hand on September 10 and 12 in 2009 and 2010, respectively, and weighed by an electronic scale, and the yield of each tree was recorded separately. Twenty fruits per treatment were sampled after harvest, and the fruit volume was measured with the water displacement method. Ten fruits from each treatment were sampled in order to measure the total soluble solids and soluble sugar content. The total soluble solids content was determined using a refraction instrument (WYT-1, Quanzhou Zhongyou Optical InstrumentCo., Ltd., Fujian, China); total soluble sugar was measured by titration with Fehling's solution.

\subsection{Data Analysis}

The experimental data were analyzed using analyses of variance. Tukey tests were used to assess the differences between means, and significant differences were based on $p<0.05$. The statistical analysis was performed using the Statistical Analysis Software (SPSS 16.0). 


\section{Results}

\subsection{Soil Water Status Affected by RDI}

Compared to the control, the amount of irrigation reduced by $5.0 \%, 9.7 \%, 18.1 \%$, and $34.7 \%$ with the treatment in MRDI-1, SRDI- 1 , MRDI- $1+2$, and SRDI- $1+2$, respectively, in 2009; the corresponding values in 2010 were $4.0 \%, 8.1 \%, 15.4 \%$, and $28.4 \%$, respectively. Consequently, this reduction in irrigation water resulted in a concomitant decrease in soil water potential during the water stress period. Additionally, the soil water potential of the control constantly maintained a higher value (ca. $-50 \mathrm{kPa}$ ) throughout the whole experimental period, which indicated less or no water stress. After RDI treatments resumed full irrigation, the soil water potential at each depth of soil layer was gradually restored, and then fluctuated in a narrow range around $-50 \mathrm{kPa}$ (Figure 2). The soil water potential in the non-irrigated zones gradually declined, and it reached approximately $-700 \mathrm{kPa}$ in the soil profile above $60 \mathrm{~cm}$ in August of 2010 (Figure 3) due to nearly no water reception in these zones during the two experimental years. Moreover, no remarkable differences in soil moisture between all treatments were observed in the non-watered zones.
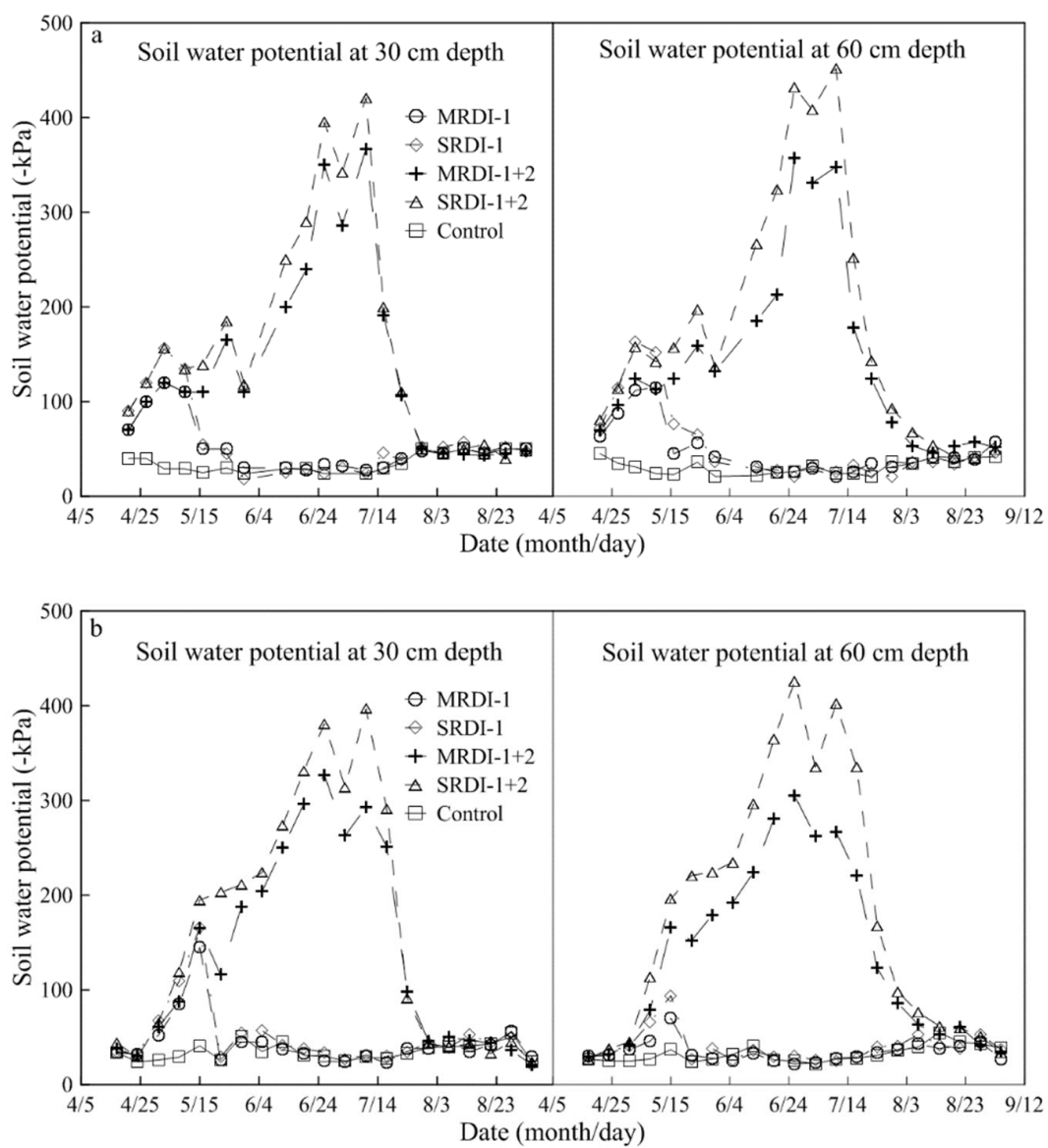

Figure 2. Soil water potential at $30 \mathrm{~cm}$ and $60 \mathrm{~cm}$ depth in irrigated zone in 2009 (a) and 2010 (b). MRDI-1 and SRDI-1 were applied with moderate and severe water stress, respectively, during Stage 1 (0-30 DAB), and fully irrigated during the other stages; MRDI-1+2 and SRDI-1+2 were applied with moderate and severe water stress, respectively, during Stage 1+2 (0-86 DAB), and fully irrigated during other stages. 


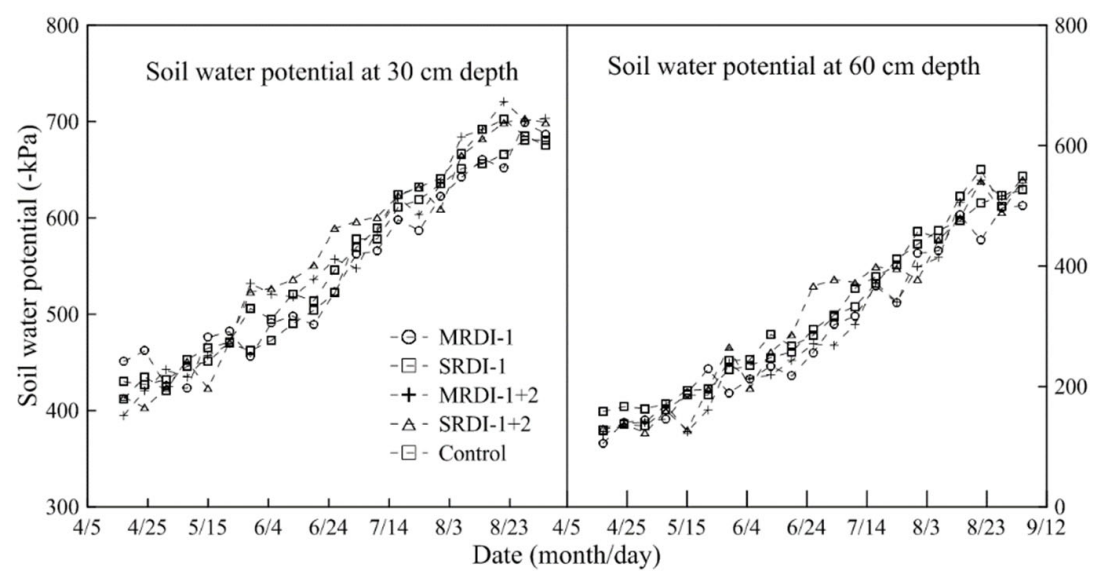

Figure 3. Soil water potential at $30 \mathrm{~cm}$ and $60 \mathrm{~cm}$ depth in non-irrigated zone in 2010. MRDI-1 and SRDI-1 were applied with moderate and severe water stress, respectively, during Stage 1 (0-30 DAB), and fully irrigated during other stages; MRDI-1+2 and SRDI-1+2 were applied with moderate and severe water stress, respectively, during Stage 1+2 (0-86 DAB), and fully irrigated during other stages.

\subsection{Responses of Fine Root Distribution to RDI Treatments}

In 2009, the highest RLD for each treatment was observed in soil layers of a 20-60 cm depth in the irrigated zones (Figure 4). In July, the RLD in the irrigated zones was significantly reduced by MRDI- $1+2$ and SRDI- $1+2$ in the $20-60 \mathrm{~cm}$ and $60-90 \mathrm{~cm}$ layers, with the exception of the 0-20 cm layer. However, there were no remarkable differences in RLD between MRDI-1, SRDI-1, and the control in the wetted root zones. After fruit harvest (150-155 DAB), enhancement of fine root development in the two deeper layers of the wetted zones under the RDI-1+2 treatments was observed, as compared to early July, and the RLD of RDI- $1+2$ treatments was similar to the control.

In 2010, the RLD in the irrigated zones was also reduced by the soil water deficit, as compared to the control (Figure 4). In May (30-35 DAB), the RLD of the RDI-1 treatments was lower than that of the control. In early July (87-90 DAB), the RLD at each soil layer of the RDI- $1+2$ treatments was significantly reduced as compared to the control, with the exception of the $0-20 \mathrm{~cm}$ layer of MRDI-1+2 (Supplementary File Figure S1). The RLD of RDI treatments was restored after the resumption of full irrigation. Especially in September, significantly higher RLD values of each RDI treatment were observed for the 20-60 cm soil layers, as compared to the control.

In the non-irrigated zones (Figure 4), in 2009, the highest RLD for each treatment was detected in the deepest soil layer $(60-90 \mathrm{~cm})$, with the exception of the 0-20 cm layer in sampling point $C$ of the control (Supplementary File Figure S2). In July, significant differences were observed for the $0-20 \mathrm{~cm}$ depth layer between the RDI-1+2 treatments and the control. However, a higher RLD in all soil layers was observed for the RDI$1+2$ treatments after the fruit harvest, as compared to the control, although significant differences were only detected between SRDI-1+2 and the control. In 2010, the RLD in all three layers under each treatment was lower than that in 2009, especially in the $0-20 \mathrm{~cm}$ layers, and the RLD in the 20-60 cm layers was higher than other two layers.

\subsection{Leaf Photosynthetic Rate, Shoot Growth, and Fruit Yield of Each Treatment}

The mean leaf photosynthetic rate values measured over three days during each stage are shown in Figure 5. During the water deficit periods, the leaf photosynthetic rate of RDI treatments was reduced; in particular, the differences between the RDI-1+2 treatments and the control were significant in Stage 2 of two consecutive experiment years. After the resumption of full irrigation, the leaf photosynthetic rate of the RDI treatments was restored, and a significantly higher leaf photosynthetic rate was observed in SRDI-1 as compared to the control during Stage 3, but the leaf photosynthetic rate of SRDI-1+2 was still significantly lower than that of the control. 


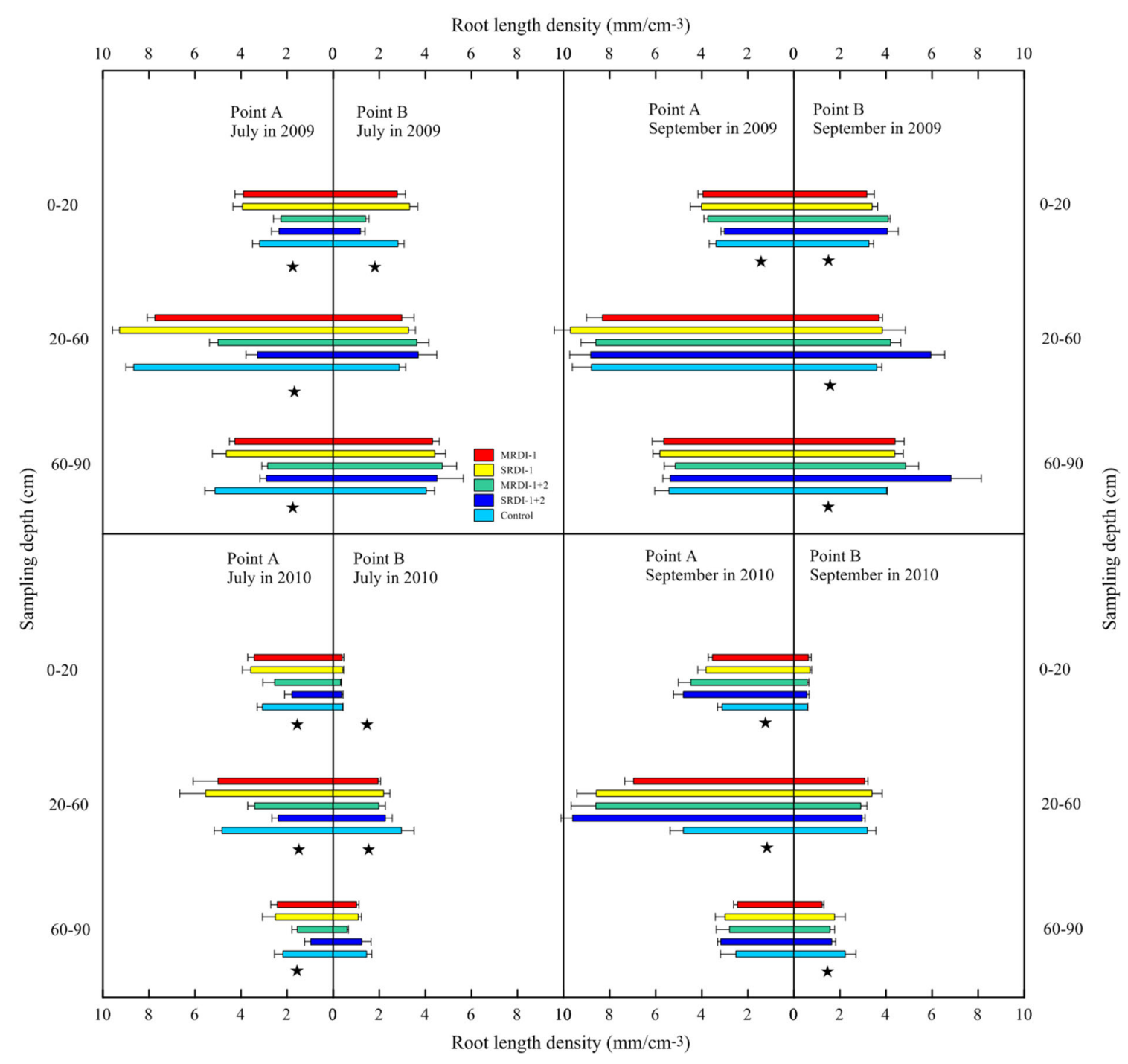

Figure 4. The root length density of each treatment. MRDI-1 and SRDI-1 were applied with moderate and severe water stress, respectively, during Stage 1 (0-30 DAB), and fully irrigated during other stages. MRDI-1+2 and SRDI-1+2 were applied with moderate and severe water stress applied, respectively, during Stage 1+2 (0-86 DAB), and fully irrigated during other stages. Sampling point A was located in the irrigated zone and sampling point B was located in the non-irrigated zone. Vertical bars represent one standard deviation of the mean. $\star$ indicates significant differences between various treatments in the same layer at the $p<0.05$ level.

The shoots grew rapidly during the cell division stage (0-30 DAB), and the shoot length of the control in late May accounted for about $90 \%$ of the final shoot length. As compared to the control, the final shoot length was reduced by $15 \%, 20 \%, 20 \%$, and $26 \%$ with MRDI-1, SRDI-1, MRDI-1+2, and SRDI-1+2 treatment, respectively, in 2009; the corresponding values in 2010 were $19 \%, 24 \%, 22 \%$, and $28 \%$, respectively. The yield of the SRDI-1 significantly increased by about $16 \%$ in 2009 and 19\% in 2010, compared to the control, and there were no significant differences in yield between MRDI-1, MRDI-1+2, and the control treatment (Table 2). However, the fruit yield was significantly reduced by the SRDI- $1+2$ in two consecutive experimental years, as compared to the control. There were no significant differences in fruit volume between all treatments. As compared to the control, the total soluble solids and soluble sugar content in the RDI treatments were similar to or higher than those of the control, with the exception of MRDI-1 in 2010. 


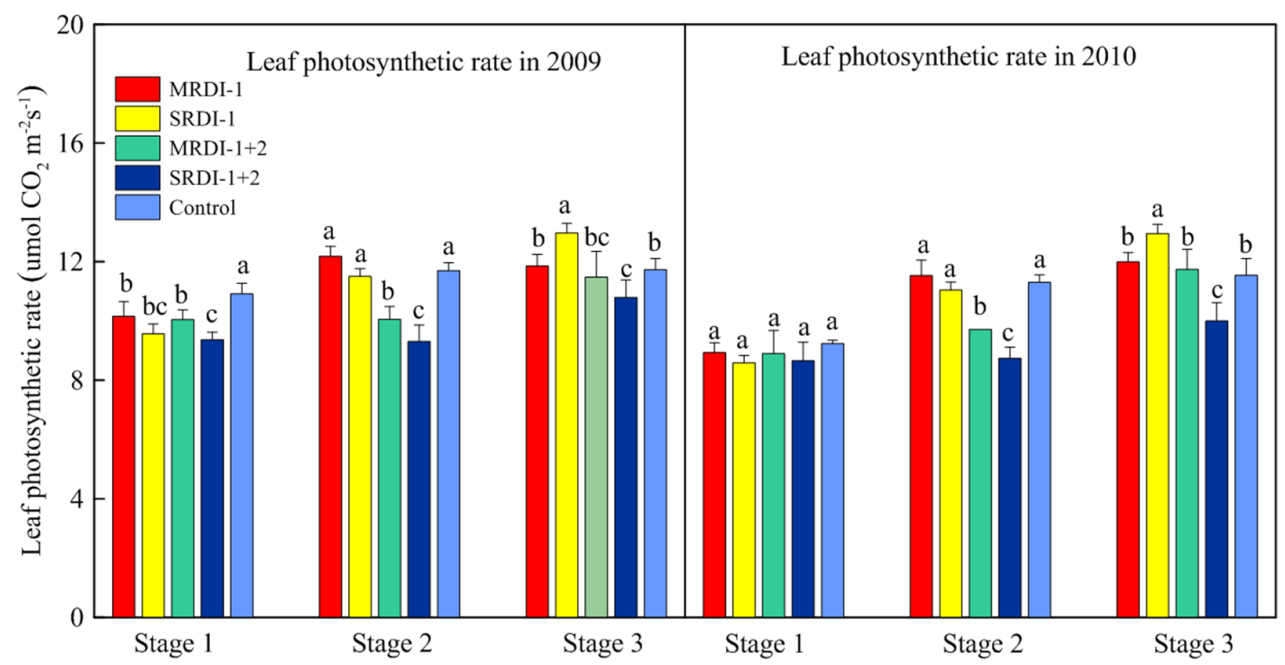

Figure 5. The leaf photosynthetic rate in three growing stages. Each value is the mean value measured over three days during each stage. Different lower letters within the same stage indicate significant differences between various treatments at the $p<0.05$ level. Vertical bars represent one standard deviation of the mean. MRDI-1 and SRDI-1 were applied with moderate and severe water stress, respectively, during Stage 1 (0-30 DAB), and fully irrigated during other stages; MRDI-1+2 and SRDI-1+2 were applied with moderate and severe water stress, respectively, during Stage 1+2 (0-86 DAB), and fully irrigated during other stages.

Table 2. Yield, fruit quality, and shoot length of each treatment.

\begin{tabular}{|c|c|c|c|c|c|c|c|}
\hline Year & Treatment & Yield (t/ha) & $\begin{array}{c}\text { Total Soluble } \\
\text { Solid } \\
\text { Content }(\%)\end{array}$ & $\begin{array}{c}\text { Soluble } \\
\text { Sugar } \\
\text { Content }(\%)\end{array}$ & Fruit Volume $\left(\mathrm{cm}^{3}\right)$ & $\begin{array}{l}\text { Final Shoot } \\
\text { Length }(\mathrm{cm})\end{array}$ & $\begin{array}{c}\text { Shoot Length } \\
\text { in Late May }(\mathrm{cm})\end{array}$ \\
\hline \multirow{5}{*}{2009} & MRDI-1 & $18.9 \mathrm{ab}$ & $12.3 \mathrm{~b}$ & $8.14 \mathrm{c}$ & $94 \mathrm{a}$ & $27.5 \mathrm{~b}$ & $25.6 \mathrm{~b}$ \\
\hline & SRDI-1 & $21.5 \mathrm{a}$ & $12.5 \mathrm{ab}$ & $8.82 \mathrm{a}$ & $100 \mathrm{a}$ & $25.9 \mathrm{bc}$ & $23.6 \mathrm{bc}$ \\
\hline & MRDI-1+2 & $18.1 \mathrm{bc}$ & $12.0 \mathrm{bc}$ & $7.97 \mathrm{c}$ & $103 \mathrm{a}$ & $26.0 \mathrm{~b}$ & $24.9 \mathrm{bc}$ \\
\hline & SRDI-1+2 & $15.8 \mathrm{c}$ & $13.1 \mathrm{a}$ & $8.61 \mathrm{~b}$ & $96 \mathrm{a}$ & $24.0 \mathrm{c}$ & $22.3 c$ \\
\hline & Control & $18.6 \mathrm{~b}$ & $11.5 \mathrm{c}$ & $6.93 \mathrm{~d}$ & $98 a$ & $32.4 \mathrm{a}$ & $30.2 \mathrm{a}$ \\
\hline \multirow{5}{*}{2010} & MRDI-1 & $21.2 \mathrm{ab}$ & $12.8 \mathrm{~b}$ & $8.08 \mathrm{a}$ & $116 \mathrm{a}$ & $25.4 \mathrm{~b}$ & $23.1 \mathrm{~b}$ \\
\hline & SRDI-1 & $23.6 \mathrm{a}$ & $13.8 \mathrm{a}$ & $8.05 \mathrm{a}$ & $123 \mathrm{a}$ & $23.9 c$ & $21.9 \mathrm{~b}$ \\
\hline & MRDI-1+2 & $20.6 \mathrm{~b}$ & $13.6 \mathrm{a}$ & $7.71 \mathrm{bc}$ & $113 \mathrm{a}$ & $24.3 \mathrm{bc}$ & $22.6 \mathrm{~b}$ \\
\hline & SRDI-1+2 & $17.2 \mathrm{c}$ & $13.9 \mathrm{a}$ & $7.99 \mathrm{ab}$ & $122 \mathrm{a}$ & $22.5 \mathrm{c}$ & $21.0 \mathrm{~b}$ \\
\hline & Control & $19.8 \mathrm{~b}$ & $13.6 \mathrm{a}$ & $7.63 \mathrm{c}$ & $114 \mathrm{a}$ & $31.3 \mathrm{a}$ & $29.1 \mathrm{a}$ \\
\hline
\end{tabular}

Note: Different letters within the same column indicate significant differences at the $p<0.05$ level. MRDI-1 and SRDI-1 were applied with moderate and severe water stress, respectively, during Stage 1 (0-30 DAB), and fully irrigated during other stages; MRDI-1+2 and SRDI-1+2 were applied with moderate and severe water stress, respectively, during Stage 1+2 (0-86 DAB), and fully irrigated during other stages. The shoot lengths in late May were measured on 20 and 21 May in 2009 and 2010, respectively; the final shoot lengths were measured on 4 September and 29 August in 2009 and 2010, respectively.

\section{Discussion}

\subsection{Fine Root Distribution in the Irrigated Zone Affected by RDI}

Abrisqueta et al. [7] indicated that the RLD of peach trees was reduced by about $73 \%$ under a continuous water deficit compared to that for well-irrigated trees. Ma et al. [37] also concluded that the total root number of grapevines significantly decreased by about $55 \%$ from high to low irrigation rates under subsurface drip irrigation. Similar results have been reported by Gao et al. [38], Ahmed et al. [39], and Ullah et al. [40]. In this study, although the fine root growth was inhibited by the water stress applied during Stage 1, significant differences in RLD were only observed between SRDI-1 and control treatments in May of 2010. The duration and degree of water stress were the key factors that controlled fine root growth. The water stress duration applied in Stage 1 (0-30 DAB) was far shorter, and the evapotranspiration during this stage was low, which resulted in relatively higher soil water tension. During Stage 2 (31-86 DAB), the shoots grew slowly, and the soil water tension was low due to the higher evaporation and water consumption of pear trees. Thus, as compared to the water stress applied in Stage 1+2, the effects of 
water stress applied in Stage 1 on fine root growth were relatively weak. The decrement in RLD increased with the decreasing irrigation amount, as compared to the MRDI-1/1+2 treatments; lower RLD values were observed for the SRDI-1/1+2 treatments in May and July, respectively. Asseng et al. [41] also indicated that the RLD at a 0-10 cm depth in non-irrigated wheat was only about $20 \%$ of that of well-irrigated wheat. Additionally, the growth of fine root was also impacted by the decline in photosynthetic products. The leaf physiological parameters were sensitive to water stress [42]; thus, water deficiency significantly reduced leaf photosynthetic rates (Figure 5), which resulted in a decline in photosynthetic product accumulation. Less photosynthetic products during water stress periods aggravated the restricted root growth. Therefore, fine root growth was inhibited with increasing degrees of water stress and decreasing photosynthetic products.

In our study, the resumption of irrigation replacing $80 \%$ of pan evaporation promoted the growth of fine root in the irrigated zone in both experimental years; in particular, at a depth of 20-60 cm in 2010, the RLD of the MRDI-1+2 and SRDI-1+2 trees sampled in September increased by almost $100 \%$ compared to that in July. Romero et al. [43] also indicated that regulated deficit irrigation applied to mature almond trees increased root dry weight below the emitter in the post-harvest period; in particular, the root dry weight at a $40-60 \mathrm{~cm}$ depth increased by about $100 \%$. The explanation of this mechanism can be found in McCully's [44] research on wheat, Opuntia ficus-indica, Lolium perenne L., and desert succulents, indicating that drought induced the development of fine root primordia, often in response to death or exhaustion of the parent root apical meristems, which are drought resistant, and, when watered, rapidly develop into fine root, resuming water and nutrient uptake. In early September 2009 (150-155 DAB), an obvious increment in RLD of MRDI-1+2 and SRDI-1+2 was observed as compared that in July of 2009, but there were no significant differences between the RDI treatments and the control. The pear trees in our experimental orchard had been flood irrigated for 24 years, and this was transformed into drip irrigation at the end of 2008. Therefore, the RLD in the wetted zone of the control pear trees increased in 2009. It is reported that drip irrigation induces fine root of apple, olive, grape, and apricot trees concentrated in irrigated zones [45-48]. In the next year, the RLD of the control decreased and restored the level of adjacent flood-irrigated pear trees (data not shown), indicating that mature pear trees needed one year to adapt to the transformation of irrigation mode by redistributing their fine root in irrigated zones.

\subsection{Fine Root Distribution in a Non-Irrigated Zone Affected by RDI}

The experimental pear trees were flood irrigated before 2009 and drip irrigated in 2009; the transformation of irrigation method resulted in the root at sampling point B and $\mathrm{C}$ not being irrigated from 2009. Therefore, the root systems in these non-irrigated regions extended deep into the soil to adapt to the transformation of the irrigation methods, which led to the higher RLD in the deeper soil layer $(60-90 \mathrm{~cm})$. Moreover, the mean RLD of the RDI-treated trees at soil layers of a depth of 20-90 cm was higher than that of the control, although there were no significant differences between each treatment. This may be due to water stress promoting the root in the non-irrigated zone to grow to adapt to the variation in the soil water environment. However, these variations did not last long. In 2010, the RLD of each treatment decreased, and as compared to the control, the RDI treatments decreased the RLD. This indicated that the fine root distributed in the wetted zone (located on each side of the pear tree rows and at a distance of $1 \mathrm{~m}$ between each side) can meet mature pear trees' water and nutrition absorption requirements. Therefore, the growth redundancy under water stress conditions, including root distributed in the non-irrigated zone and shoot, was restricted in order to adapt to the decline in photosynthetic products and to maintain the reproductive growth of the mature pear trees.

\subsection{Leaf Photosynthetic Rate, Shoot Growth, and Fruit Yield Affected by RDI}

After the resumption of full irrigation, the recovery of the leaf photosynthetic rate depended on the duration and degree of the previous soil water deficit. Compared to 
Stage 2, a similar leaf photosynthetic rate for MRDI-1 was observed in Stage 3, but a clearly higher leaf photosynthetic rate was observed for SRDI-1. This may be because the severe water stress treatment required more time for the recovery of the leaf photosynthetic rate, as compared to the moderate water stress treatment. Similar results were reported by Ramos and Santos [49] in olive trees and by Fereres et al. [50] in orange trees. Moreover, significantly lower values of SRDI-1+2 were observed during the fruit enlargement stage, as compared to the control. This indicated that the long period and severe water stress resulted in the leaf photosynthetic rate not fully recovering, even after the resumption of full irrigation. This may lead to insufficient photosynthetic products in the fruit enlargement stage (87-147 DAB).

In our research, as compared to the control, the fine root length of the MRDI-1 and SRDI-1 treatments in the irrigated zones was reduced by $8 \%$ and $18 \%$, respectively, in May of 2010; it was less than the decline in the final shoot length (Table 2). This indicated that the water stress applied during the shoot rapid growth stage (0-30 DAB) restricted shoot growth more than the fine root growth. Kramer et al. [12] indicated that root growth of loblolly and scotch pine seedlings in slowly drying soil was reduced to about $25 \%$ of the rate at field capacity, and shoot growth was reduced much more than root growth in drying soil. Huang et al. [51] indicated that the root to shoot dry weight ratio of high fescue in well-watered conditions was about 0.01 , and that in drought stress conditions was about 0.015-0.02. Similar results were reported by Romero et al. [43] in mature almond trees. However, until early July (87-90 DAB) in both experimental years, the fine root length of SRDI-1+2 decreased by $53 \%$ and $50 \%$, respectively, but there were no significant differences in the shoot length of SRDI-1+2 between May and September; a similar phenomenon was also observed in MRDI-1+2. The shoot growth of the mature pear trees nearly stopped in Stage 2 (31 to $86 \mathrm{DAB}$ ); thus, water stresses imposed in this period did not impact the shoot growth negatively [23]; only the root growth was inhibited by the water stress applied in this stage. This indicated that water stress imposed only in the vegetative growth stage (Stage 1) can effectively improve the root/shoot ratio of pear trees, and water stress applied during the slow growth period of both shoots and fruit mainly inhibited fine root development.

The redistribution of RLD in various treatments had different impacts on the fruit yield of pear trees. The RLD in the irrigated zones of SRDI-1 recovered before the fruit enlargement stage, and a higher RLD of SRDI-1 was observed in September, as compared to the control, although the differences in 2009 were not significant. These maintained the sufficient absorption of nutrients and water during the following fruit enlargement stage (87-147 DAB), which met the requirements for fruit enlargement and led to a higher yield. Sokalska et al. [34] concluded that apple trees that have more fine root have a higher fruit yield. Tanasescu and Paltineanu [52] also found a linear correlation between the crosssectional area of active tree root and the yield of apple trees. The research on hot peppers also indicates that mean primary root length shows a significant positive correlation with final fruit yield under normal and water stress conditions [11]. Moreover, the significantly higher leaf photosynthetic rate of SRDI-1-treated trees during the fruit enlargement stage also maintained the improvement of final fruit yield. However, the MRDI-1-treated trees had a similar fruit yield to those of the control. Although the RLD of MRDI- 1 in the irrigated zones also recovered before the fruit enlargement stage, the vegetative growth of MRDI-1 was closer to that of the control, as compared to SRDI-1, which resulted in a similar nutrient consumption during the shoot growth stage in both the MRDI- 1 and control. A similar leaf photosynthetic rate in both the MRDI-1 and the control was also observed during the fruit enlargement stage (87-147 DAB). Therefore, the recovery of RLD in July was not enough to increase the fruit yield of MRDI-1. As compared to the control, the significantly lower RLD in MRDI-1+2 and SRDI-1+2-treated trees in early July (87-90 DAB) impacted pear trees' water and nutrient absorption. The fine root system preferentially grew to maintain the capability of nutrient and water absorption; thus, fruit growth may be inhibited during the subsequent fruit enlargement stage (87-147 DAB). Kramer and 
Boyer [12] and Moreno et al. [53] also indicated that plants, being subjected to severe water stress, usually do not regain their full capacity to absorb water until several days after the soil is rewetted. Especially in SRDI-1+2, long-term, severe water stress significantly inhibited the growth of pear trees, and the decrement in aboveground vegetative structure growth and fine root before the fruit enlargement stage (0-86 DAB) resulted in significantly decreased photosynthetic products and water and nutrient uptake, respectively, from the soil. Thus, more time was needed for the root system to recover, so the fruit growth during Stage 3 was negatively influenced. Additionally, fruit growth may also be impaired by long-term, severe water stress imposed before the fruit enlargement stage. Moreover, the leaf photosynthetic rate of SRDI-1+2 was significantly lower than that of the control during the fruit enlargement stage (Figure 5). The limited photosynthetic products were transferred to support fruit growth, which was another reason for the decline in fruit yield. However, the inhibition of the root system in MRDI-1+2 was less than that of SRDI-1+2, so the MRDI-1+2 treatment required less time to restore the root system, which ensured water and nutrient absorption during the fruit enlargement stage and maintained final fruit yield.

The various RDI treatments had no impacts on the final fruit volume. A study on olive trees also concluded that the fresh and dry weight of fruits are not impacted by different irrigation amounts [54]. The total soluble solids content was significantly improved by the severe water deficit treatments in 2009, with the exception of MRDI-1+2 in 2009, but a similar phenomenon was not observed in 2010. As compared to the control, the soluble sugar content was significantly improved by all RDI treatments in two experiment years, with the exception of MRDI-1+2 in 2010. However, Marsal et al. [22] indicated that water stress imposed on fruit slowly during the enlargement stage reduced the sugar content of pear fruit. Therefore, it is worth further researching the effects of water deficit applied before the fruit enlargement stage on the fruit quality of pear trees.

\section{Conclusions}

The water deficit applied before the fruit enlargement stage (0-86 DAB) inhibited fine root and shoot growth in the irrigated zones, but only the water stress applied during the cell division stage (fast shoot growth stage, 0-30 DAB) inhibited shoot development more effectively than root growth due to the near cessation of shoot growth in other stages (31-147 DAB). The resumption of full irrigation boosted fine root growth of previously water-stressed trees in the irrigated zones. The RLD of SRDI-1-treated trees in the irrigated zones recovered before the fruit enlargement stage (87-90 DAB) and maintained water and nutrient absorption during the fruit enlargement stage (87-147 DAB), which resulted in significantly higher fruit yields as compared to the controls. However, there were no significant differences in fruit yield between the MRDI-1 and the control treatments. The leaf photosynthetic rate in Stage 3 and the final vegetative growth of MRDI-1 were closer to those of the control than SRDI-1, which may result in a similar fruit yield of both the MRDI-1 and the control. Severe and long-term water stress significantly reduced the RLD of SRDI-1+2-treated trees before early July (87-90 DAB), resulting in deficiency of water and nutrient during the fruit enlargement stage; thus, fruit growth was inhibited and fruit yield was decreased. As compared to the control, no significant differences in the fruit yield of MRDI-1+2-treated trees were observed. This indicated that the root system of MRDI-1+2-treated trees was restored quickly in order to maintain water and nutrient absorption after the resumption of full irrigation in Stage 3; thus, the final fruit yield was not negatively impacted. Therefore, the severe water stress imposed in Stage 1 can maintain the fine root length density during the fruit enlargement stage, and significantly increase the fruit yield of pear trees; the moderate water stress applied in Stage 1 or Stage 1+2 had no impacts on the fruit yield, but it could reduce irrigation amount and increase water use efficiency in a desert climate.

Supplementary Materials: The following are available online at https: / www.mdpi.com/article / 10.3390/agronomy11112316/s1, Figure S1: The root length density of MRDI-1, SRDI-1 and control; Figure S2: The root length density of each treatment. 
Author Contributions: Conceptualization, Y.W. and S.L.; methodology, Y.W., Z.Z., and S.L.; investigation, Y.W., F.Z., X.C. and P.Z.; resources, Z.Z.; data curation, F.Z., X.C. and P.Z.; visualization, Z.Z., F.Z., X.C. and P.Z.; writing—original draft, Y.W.; writing—review and editing, Y.W. and S.L.; funding acquisition, Y.W. All authors have read and agreed to the published version of the manuscript.

Funding: The project was financed by the Presidential Foundation of the Beijing Academy of Forestry and Pomology Sciences, Project number: 201902; National Key Technology R\&D Program of China, Project number: 2007BAD38B00; and the China National Natural Science Fund, Project number: 50879087.

Institutional Review Board Statement: Not applicable.

Informed Consent Statement: Not applicable.

Data Availability Statement: The data presented in this study are available on request from the corresponding author.

Conflicts of Interest: The authors declare that they have no conflict of interest.

\section{References}

1. Mia, M.J.; Furmanczyk, E.M.; Golian, J.; Kwiatkowska, J.; Malusá, E.; Neri, D. Living Mulch with Selected Herbs for Soil Management in Organic Apple Orchards. Horticulturae 2021, 7, 59. [CrossRef]

2. Wang, J.; Du, G.; Tian, J.; Zhang, Y.; Jiang, C.; Zhang, W. Effect of irrigation methods on root growth, root-shoot ratio and yield components of cotton by regulating the growth redundancy of root and shoot. Agric. Water Manag. 2020, 234, 106120. [CrossRef]

3. Ong, C.K.; Corlett, J.E.; Singh, R.P.; Black, C.R. Above and below ground interactions in agroforestry systems. For. Ecol. Manag. 1991, 45, 45-57. [CrossRef]

4. Oppelt, A.L.; Kurth, W.; Jentschke, G.; Godbold, D.L. Contrasting rooting patterns of some arid-zone fruit tree species from Botswana-I. Fine root distribution. Agrofor. Syst. 2005, 64, 1-11. [CrossRef]

5. Sansavini, S.; Ancarani, V.; Neri, D. Overview of intensive pear culture: Planting density, rootstocks, orchard management, soil-water relations and fruit quality. Acta Hortic. 2008, 800, 35-49. [CrossRef]

6. Steinberg, S.L.; Miller, J.C.; Mcfarland, M.J. Dry matter partitioning and vegetative growth of young peach trees under water stress. Aust. J. Plant Physiol. 1990, 17, 23-36. [CrossRef]

7. Abrisqueta, J.M.; Mounzer, O.; Álvarez, S.; Conejero, W.; García-Orellana, Y.; Tapia, L.M.; Vera, J.; Abrisqueta, I.; Ruiz-Sánchez, M.C. Root dynamics of peach trees submitted to partial rootzone drying and continuous deficit irrigation. Agric. Water Manag. 2008, 95, 959-967. [CrossRef]

8. Musacchi, S.; Iglesias, I.; Neri, D. Training Systems and Sustainable Orchard Management for European Pear (Pyrus communis L.) in the Mediterranean Area: A Review. Agronomy 2021, 11, 1765. [CrossRef]

9. Ahmadi, S.H.; Plauborg, F.; Andersen, M.N.; Sepaskhah, A.R.; Jensen, C.R.; Hansen, S. Effects of irrigation strategies and soils on field grown potatoes: Root distribution. Agric. Water Manag. 2011, 98, 1280-1290. [CrossRef]

10. Li, F.; Liu, X.; Li, S. Effects of early soil water distribution on the dry matter partition between roots and shoots of winter wheat. Agric. Water Manag. 2001, 49, 163-171. [CrossRef]

11. Kulkarni, M.; Phalke, S. Evaluating variability of root size system and its constitutive traits in hot pepper (Capsicum annum L.) under water stress. Sci. Hortic. 2009, 120, 159-166. [CrossRef]

12. Kramer, P.J.; Boyer, J.S. Water Relations of Plants and Soils; Academic Press: San Diego, CA, USA, 1995; pp. 145-147.

13. Chalmers, D.J.; Mitchell, P.D.; Van Heek, L. Control of peach tree growth and productivity by regulated water supply, tree density, and summer pruning. J. Am. Soc. Hortic. Sci. 1981, 106, 307-312.

14. Tognetti, R.; d'Andria, R.; Morelli, G.; Alvino, A. The effect of deficit irrigation on seasonal variations of plant water use in Olea europaea L. Plant Soil 2005, 273, 139-155. [CrossRef]

15. Mitchell, P.D.; Jerie, P.H.; Chalmers, D.J. The effects of regulated water deficits on pear tree growth, flowering, fruit growth, and yield. J. Am. Soc. Hortic. Sci. 1984, 109, 604-606.

16. Ahumada-Orellana, L.E.; Ortega-Farías, S.; Searles, P.S.; Retamales, J.B. Yield and water productivity responses to irrigation cut-off strategies after fruit set using stem water potential thresholds in a super-high density olive orchard. Front. Plant Sci. 2017, 8, 1280. [CrossRef] [PubMed]

17. Mitchell, P.D.; Chalmers, D.J.; Jerie, P.H.; Burge, G. The use of initial withholding of irrigation and tree spacing to enhance the effect of regulated deficit irrigation on pear trees. J. Am. Soc. Hortic. Sci. 1986, 111, 858-861.

18. Mitchell, P.D.; van den Ende, B.; Jerie, P.H.; Chalmers, D.J. Responses of 'Bartlett' pear to withholding irrigation, regulated deficit irrigation, and tree spacing. J. Am. Soc. Hortic. Sci. 1989, 114, 15-19.

19. Caspari, H.W.; Behboudian, M.H.; Chalmers, D.J. Water use, growth, and fruit yield of 'Hosui' Asian pears under deficit irrigation. J. Am. Soc. Hortic. Sci. 1994, 119, 383-388. [CrossRef]

20. Chalmers, D.J.; Burge, G.; Jerie, P.H.; Mitchell, P.D. The mechanism of regulation of 'Bartlett' pear fruit and vegetative growth by irrigation withholding and regulated deficit irrigation. J. Am. Soc. Hortic. Sci. 1986, 111, 904-907. 
21. Behboudian, M.H.; Lawes, G.S.; Griffiths, K.M. The influence of water deficit on water relations, photosynthesis and fruit growth in Asian pear (Pyrus serotina Rehd.). Sci. Hortic. 1994, 60, 89-99. [CrossRef]

22. Marsal, J.; Rapoport, H.F.; Manrique, T.; Girona, J. Pear fruit growth under regulated deficit irrigation in container-grown trees. Sci. Hortic. 2000, 85, 243-259. [CrossRef]

23. Wu, Y.; Zhao, Z.; Wang, W.; Ma, Y.; Huang, X. Yield and growth of mature pear trees under water deficit during slow fruit growth stages in sparse planting orchard. Sci. Hortic. 2013, 164, 189-195. [CrossRef]

24. Çolak, Y.B.; Yazar, A. Evaluation of crop water stress index on Royal table grape variety under partial root drying and conventional deficit irrigation regimes in the Mediterranean Region. Sci. Hortic. 2017, 224, 384-394. [CrossRef]

25. De la Hera, M.L.; Romero, P.; Gómez-Plaza, E.; Martinez, A. Is partial root-zone drying an effective irrigation technique to improve water use efficiency and fruit quality in field-grown wine grapes under semiarid conditions? Agric. Water Manag. 2007, 87, 261-274. [CrossRef]

26. Egea, G.; González-Real, M.M.; Baille, A.; Nortes, P.A.; Sánchez-Bel, P.; Domingo, R. The effects of contrasted deficit irrigation strategies on the fruit growth and kernel quality of mature almond trees. Agric. Water Manag. 2009, 96, 1605-1614. [CrossRef]

27. Egea, G.; Nortes, P.A.; González-Real, M.M.; Baille, A.; Domingo, R. Agronomic response and water productivity of almond trees under contrasted deficit irrigation regimes. Agric. Water Manag. 2010, 97, 171-181. [CrossRef]

28. Blanco, V.; Torres-Sánchez, R.; Blaya-Ros, P.J.; Pérez-Pastor, A.; Domingo, R. Vegetative and reproductive response of ‘Prime Giant' sweet cherry trees to regulated deficit irrigation. Sci. Hortic. 2019, 249, 478-489. [CrossRef]

29. Cuevas, J.; Cañete, M.L.; Pinillos, V.; Zapata, A.J.; Fernández, M.D.; González, M.; Hueso, J.J. Optimal dates for regulated deficit irrigation in 'Algerie' loquat (Eriobotrya japonica Lindl.) cultivated in Southeast Spain. Agric. Water Manag. 2007, 89, 131-136. [CrossRef]

30. Hueso, J.J.; Cuevas, J. Loquat as a crop model for successful deficit irrigation. Irrig. Sci. 2008, 26, 269-276. [CrossRef]

31. Hueso, J.J.; Cuevas, J. Ten consecutive years of regulated deficit irrigation probe the sustainability and profitability of this water saving strategy in loquat. Agric. Water Manag. 2010, 97, 645-650. [CrossRef]

32. Tejero, I.G.; Zuazo, V.H.D.; Bocanegra, J.A.J.; Fernández, J.L.M. Improved water-use efficiency by deficit-irrigation programmes: Implications for saving water in citrus orchards. Sci. Hortic. 2011, 128, 274-282. [CrossRef]

33. Yan, Q.; Wang, W.; Ren, D.; Wu, Y.; Ma, Y.; Huang, X. Effects of wetted percentage on the root redistribution of mature Korla fragrant pear trees under drip irrigation. J. Irrig. Drain. 2011, 30, 63-67.

34. Sokalska, D.I.; Haman, D.Z.; Szewczuk, A.; Sobota, J.; Dereń, D. Spatial root distribution of mature apple trees under drip irrigation system. Agric. Water Manag. 2009, 96, 917-924. [CrossRef]

35. Persson, H.; Fircks, Y.V.; Majdi, H.; Nilsson, L.O. Root distribution in a Norway spruce (picea abies (L.) Karst.) stand subjected to drought and ammonium-sulphate application. Plant Soil 1995, 168, 161-165. [CrossRef]

36. Wonisch, A.; Tausz, M.; Müller, M.; Weidner, W.; Dekok, L.J.; Grill, D. Treatment of young spruce shoots with SO2 and H2S: Effects on fine root chromosomes in relation to changes in the thiol content and redox state. Water Air Soil Pollut. 1999, 116, 423-428. [CrossRef]

37. Ma, X.; Sanguinet, K.A.; Jacoby, P.W. Direct root-zone irrigation outperforms surface drip irrigation for grape yield and crop water use efficiency while restricting root growth. Agric. Water Manag. 2020, 231, 105993. [CrossRef]

38. Gao, Y.; Zhang, M.; Yao, C.; Liu, Y.; Wang, Z.; Zhang, Y. Increasing seeding density under limited irrigation improves crop yield and water productivity of winter wheat by constructing a reasonable population architecture. Agric. Water Manag. 2021, 253, 106951. [CrossRef]

39. Ahmed, A.; Alfalahi, H.M.; Al-Abodi, K.; Bassam, K.; Jabbar, A.; Amer, M.M.; Khiadher, A.S. Scheduling irrigation as a water saving practice for corn (Zea mays L.) production in Iraq. Int. J. Appl. Agric. Sci. 2015, 1, 55-59.

40. Ullah, I.; Mao, H.; Rasool, G.; Gao, H.; Javed, Q.; Sarwar, A.; Khan, M.I. Effect of Deficit Irrigation and Reduced N Fertilization on Plant Growth, Root Morphology and Water Use Efficiency of Tomato Grown in Soilless Culture. Agronomy 2021, 11, 228. [CrossRef]

41. Asseng, S.; Ritchie, J.T.; Smucker, A.J.M.; Robertson, M.J. Root growth and water uptake during water deficit and recovering in wheat. Plant Soil 1998, 201, 265-273. [CrossRef]

42. Mossad, A.; Scalisi, A.; Lo Bianco, R. Growth and water relations of field-grown'Valencia' orange trees under long-term partial rootzone drying. Irrig. Sci. 2018, 36, 9-24. [CrossRef]

43. Romero, P.; Botía, P.; Garcia, F. Effects of regulated deficit irrigation under subsurface drip irrigation conditions on water relations of mature almond trees. Plant Soil 2004, 260, 155-168. [CrossRef]

44. McCully, M. Roots in soil: Unearthing the complexities of roots and their rhizospheres. Annu. Rev. Plant Physiol. Plant Mol. Biol. 1999, 50, 695-718. [CrossRef] [PubMed]

45. Levin, I.; Assaf, R.; Bravdo, B. Soil moisture and root distribution and an apple orchard irrigated by tricklers. Plant Soil 1979, 52, 31-40. [CrossRef]

46. Fernández, J.E.; Moreno, F.; Cabrera, F.; Arrue, J.L.; Martín-Aranda, J. Drip irrigation, soil characteristics and the root distribution and root activity of olive trees. Plant Soil 1991, 133, 239-251. [CrossRef]

47. Stevens, R.M.; Douglas, T. Distribution of grapevine roots and salt under drip and full-ground cover microjet irrigation systems. Irrig. Sci. 1994, 15, 147-152. [CrossRef] 
48. Ruiz-Sánchez, M.C.; Plana, V.; Ortuño, M.F.; Tapia, L.M.; Abrisqueta, J.M. Spatial root distribution of apricot trees in different soil tillage practices. Plant Soil 2005, 272, 211-221. [CrossRef]

49. Ramos, A.F.; Santos, F.L. Yield and olive oil characteristics of a low-density orchard (cv. Cordovil) subjected to different irrigation regimes. Agric. Water Manag. 2010, 97, 363-373. [CrossRef]

50. Fereres, E.; Cruz-Romero, G.; Hoffman, G.J.; Rawlins, S.L. Recovery of orange trees following severe water stress. J. Appl. Ecol. 1979, 16, 833-842. [CrossRef]

51. Huang, B.; Fry, J.D. Root anatomical, physiological and morphological responses to drought stress for tall Fescue cultivars. Crop Sci. 1998, 38, 1017-1022. [CrossRef]

52. Tanasescu, N.; Paltineanu, C. Root distribution of apple tree under various irrigation systems within the hilly region of Romania. Int. Agrophysics 2004, 18, 175-180.

53. Moreno, F.; Fernández, J.E.; Clothier, B.E.; Green, S.R. Transpiration and root water uptake by olive trees. Plant Soil 1996, 184, 85-96. [CrossRef]

54. Lodolini, E.M.; Polverigiani, S.; Ali, S.; Mutawea, M.; Qutub, M.; Pierini, F.; Neri, D. Effect of complementary irrigation on yield components and alternate bearing of a traditional olive orchard in semi-arid conditions. Span. J. Agric. Res. 2016, 14, e1203. [CrossRef] 